\title{
THE FINNISH EXCLUSIVE-NEGATIVE CONSTRUCTION EI...KU(I)N IN THE NETWORK OF EXCLUSION EXPRESSIONS
}

\author{
Maria Vilkuna \\ University of Helsinki, FI \\ maria.vilkuna@helsinki.fi
}

\begin{abstract}
This paper shows that Finnish has the option of expressing 'only'-like exclusive meaning with a clausal construction, here called the Exclusive-Negative Construction, ENC. It is similar to the better-known French ne...que construction but differs from it at many points where Finnish and French grammar differ, especially in the way negation is expressed in the two languages. The Finnish ENC contains overt negation, which accounts for its somewhat narrower distribution than the alternative option, the use of the focus particle vain/vaan 'only'. Adopting the Construction Grammar framework, the paper argues that the ENC is a simple clausal construction with the idiosyncrasy of mixed polarity, a formal division of the clause into a negative and affirmative part. Derivation from an underlying comparative is rejected, but it is shown that the ENC has associations to more explicit ways of expressing exclusion. These conclusions receive support from dialectal and other non-standard data.
\end{abstract}

Keywords: ne..que construction, focus particle, exclusive, exceptive, negation, construction grammar, Finnish, French

DOI: https://doi.org/10.12697/jeful.2021.12.1.13

\section{Introduction}

Finnish has two ways of expressing exclusion of alternatives to a focused element, the exclusive focus particle vain/vaan in (1), and the clausal construction in (2). The latter is reminiscent of the French $n e . .$. que construction (3). All three examples can be translated 'I have only one cow'.
(1) Minulla
on
vain $y k s i$
lehmä.
1SG:ADE
be. $3 \mathrm{SG}$
only
one
cow 
$\begin{array}{llllll}\text { (2) Minulla } & \text { ei } & \text { ole } & \text { kuin } & y k s i & \text { lehmä. } \\ \text { 1sG:ADE } & \text { NEG.3sG } & \text { be.CNG } & \text { KUIN } & \text { one } & \text { cow }\end{array}$

$\begin{array}{llll}\text { (3) Je } & \text { n'ai } & \text { qu'une } & \text { vache. } \\ \text { 1SG } & \text { NEG:have:1PL } & \text { QUE:INDEF } & \text { cow }\end{array}$

The topic of this paper is the Finnish construction in (2). On the analogy of the term exclusive focus particle (König 1991), I call it the Exclusive-Negative Construction, abbreviated ENC. The construction is negative in form, but the negation is not quite complete. The connection to negation is stronger in Finnish than in French, where the element ne needs the support of words such as pas to indicate actual negation. In the ne...que construction, ne can also be absent, leaving the particle que as solely responsible for the exclusive meaning (Gaatone 1999: 104106). In Finnish, overt negation is an integral part of the construction (with exceptions to be discussed below). In both languages, negationrelated phenomena seem to affect only the grammar of the initial part of the clause. Both languages employ a particle, que or kuin/kun, which is also used (inter alia) in comparative constructions to mark the standard of comparison, and in both languages a word meaning 'other' can generally be inserted before this particle, making the pattern more transparent and compositional. This paper argues that even though the construction is evidently based on comparative constructions and the word 'other', the exclusive meaning is created by the construction itself.

Accounting for the ne...que construction has typically involved derivation via ellipsis or silent elements in the Generative tradition (Dekydspotter 1993, O'Neill 2011, Homer 2015, Authier 2020 among others) - as expected, since even comparative constructions have typically received such a treatment. Another strategy has been to give que a category and semantic description unique to this construction (Rooryck 2018). The present paper adopts the Construction Grammar framework (abbreviated Cxg; see e.g. Goldberg 1995, 2006, Fried 2015, Diessel 2019), in which constructions are seen as the basic units of grammar. Constructions are not derived from underlying structures, and the question of ellipsis is answered in a different way (Goldberg \& Perek 2018). That the Finnish ENC is a construction in its own right means that it is a conventional form-meaning pair, even if it has connections to other patterns expressing comparison or exclusion. The ENC qualifies as a 
construction as it deviates from canonical patterns in a number of ways (see Hilpert 2014: 14-22). The idea of the ENC as a construction is thus quite conservative, for it is a "special" pattern of the type common in early work within the constructional framework, where the importance of constructions was justified by pointing at conventionalized patterns that exhibited properties not easily accommodated in the general picture of the grammar of the language in question (for Finnish, e.g. Kotilainen 2007; see Goldberg 2013 for variants of $\mathrm{CxG}$ ). This view is compatible with a model of grammar that allows more predictable grammatical structures to be built by general rules. The present paper is not a defence of that kind of model but remains neutral with respect to the different theoretical and technical directions among constructional frameworks.

Although inspired by a contrastive observation about Finnish and French, this paper is not primarily contrastive in nature but aims at the description of the Finnish ENC and its relationship with certain other Finnish constructions. The paper is the first study on the Finnish ENC to my knowledge, although observations on the phenomenon can be met in early treatments of dialect syntax (see section 4.2), certain examples in the Dictionary of Modern Finnish (NS 1963 s.v. kuin) and in the grammar Hakulinen et al. (2004: § 1176).

The data for this paper come from various searches from Finnish corpora, using the Korp concordance interface (korp.csc.fi), but also from occasional observations. Two corpora have a special status. One is the Syntax Archives (LA) dialect interview corpus of over one million words, consisting of interviews recorded with elderly speakers born in the late nineteenth century. My basic dataset is 433 occurrences of ENC in this corpus. The other central corpus is the Suomi24 discussion forum, comprising at present over 4 billion words. Both corpora provide access to the discussion context. The ENC is used in all dialects and is not stylistically restricted but occurs in genres from academic publications (see (16) for an example) to everyday conversation. Still, nonstandard data have proved to be especially relevant, for dialectal speech and non-standard writing very often encountered on discussion forums bring to light interesting borderline cases and even patterns I had not been aware of before.

The use of corpora for the purposes of the present paper is exploratory rather than strictly corpus linguistic. Representative examples of the ENC and related patterns are not hard to find by corpus searches, but 
compiling data for statistic calculations is extremely time-consuming because the actual words used in the relevant constructions are polyfunctional and also because they exhibit considerable phonological and orthographical variation in the non-standard varieties. In what follows, capitalied KUIN stands for the ENC particle (example 2), covering all its actual realizations such as $k u i n, k u(n) k o(n), k \ddot{o}$, and capitalized vaIN is used for the focus particle 'only' in (1), with the main variants vain and vaa(n). ${ }^{1}$ The diphthongs $u i$ and $a i$ in these words correspond to simple vowels in non-standard usage. The standard language makes a distinction between kuin and kun such that only kuin should be used in constructions with a comparative meaning ('than, like, as'), which is the relevant meaning in the present context, while kun is a temporal and causal conjunction. Non-standard varieties do not make this difference (see Ikola, Palomäki \& Koitto 1989: 89-97, Herlin 1998: 21), which makes it necessary to hand-pick the relevant instances of the very frequent kun from all search results. As for VAIN 'only', its colloquial form $v a a(n)$ is restricted to use as a conjunction in contrastive negation in standard Finnish (Ikola, Palomäki \& Koitto 1989: 54-60, Silvennoinen 2020). My notation and also my choice of written examples are somewhat biased towards standard spelling. The examples are given in their original form but often slightly abbreviated; invented examples used for clarifying grammatical contrasts are recognizable from the lack of source marking.

Section 2 of this paper is a description of the ENC. After a general definition (2.1), its negativity properties (2.2.) and its general structural options (2.3.) are presented, mainly from the structural point of view. The ENC and the focus particle vaIN are compared in section 3, where it will be seen that VAIN has a wider distribution and meaning. Section 4 is dedicated to the connections between ENC and other syntactic patterns used to express exclusion. These include KuIN used in comparison constructions (4.1), the word muu 'other', which has a special place in my hypothesis about the constructionalization of the ENC (4.2), and exceptives such as paitsi 'except' (4.3). Section 5 briefly summarizes the network of exclusion constructions in which the ENC is a member and Section 6 concludes the paper.

1 In spoken language, the final $-n$ of both words may be fully reduced or assimilate to the following consonant. 


\section{The structure of the ENC}

\subsection{The construction}

The Finnish ENC is a clausal construction (Hoffmann 2013) that consists of negation and the particle KUIN followed by a slot for a focus phrase, henceforth called E-focus ('exclusion focus'). The construction can be provisionally described as in (4), where $\mathrm{X}, \mathrm{Y}$ and $\mathrm{Z}$ stand for any linguistic material that can be instantiated in the clause in addition to negation (NEG), KUIN and the E-focus. X, Y and Z may be null, but the overt presence of $\mathrm{Z}$ is not common, i.e. the $\mathrm{E}$-focus is generally final in the clause. KUIN forms a constituent together with its complement phrase, which is specified for referential meaning 'f.' (In Section 5, a possible addition to KUIN will be considered.)

\section{(4) Form: Clause $[X$ NEG Y [KUIN Foc[Meaning: Ref: f]] Z] \\ Meaning: ' $X Y Z$ ' applies to $f$ and to no $x$ such that $x \neq f$}

Since the aim of this paper is descriptive, I will not attempt to construe a technically complete representation; the issue is complicated as the variable parts $\mathrm{X}, \mathrm{Y}$ and $\mathrm{Z}$ must be considered as semantic entities in the meaning pole of the construction. NeG is a shorthand for the negation marker itself and the morphosyntactic properties it inherits from the general clausal negation; the marker is usually the auxiliary ei (in the imperative, $\ddot{a} l$-), inflected for person (see e.g. Vilkuna 2015). The E-focus takes many forms and can have the role of an argument, adjunct and even a predicate in the clause.

The meaning pole in (4) is modelled after standard treatments of exclusive focus particles (e.g. König 1991: 37). In the case of sentence (2), $\mathrm{X}$ and $\mathrm{Y}$ consist of 'I' and 'have', $\mathrm{f}$ is 'a cow', and we learn that the speaker has a cow and that she has nothing that is not a cow. For simplicity, this description is restricted to non-scalar readings, where the alternatives of the focus value are simply excluded. Such alternatives are contextual and depend on the participants' orientation. Thus the utterance 'I have only one cow' could be viewed against kinds of domestic animals, excluding pigs, horses and sheep, or against any potential possessions or even company that the speaker might (but does not) have. A more complete description must, inter alia, represent the 
scalar use of the construction (König 1991: 99-100), where the alternatives are ordered in a scale and only values higher on the scale than ' $\mathrm{f}$ ' are excluded. ${ }^{2}$ Because of the numeral 'one', the first reading to come to mind in the case of (2) is the scalar reading excluding a bigger number of cattle. Scalar readings are likely to be highly conventional when the E-focus includes numbers or other measures of quantity, distance or time, e.g. (5). ${ }^{3}$

(5) Keittiönhana vuotaa juuresta, '(My) kitchen faucet leaks at the base'

$\begin{array}{llll}\text { eikä } & \text { ole } & \text { kuin } & \text { kuusivuotias. (S24 2012) } \\ \text { neg }=\text { CL be.CNG } & \text { KUIN } & \text { six:year:ADJ } \\ \text { 'and is only six years old.' } & \end{array}$

The description in (4) could also be adjusted for a better match with Finnish constituent order (Vilkuna 1989, Hakulinen et al. 2004: 13721388). An important property of the ENC is that the E-focus is confined to the post-verbal part of the sentence, more specifically the field that typically starts with the verb and is preceded for the Topic position, the normal place of the subject. Only the focus particle vaIN can mark the subject in this position as the E-focus (6a). ${ }^{4}$ An E-focus that functions as the subject is placed in the post-verbal part, if possible (6b); this position also hosts narrowly focused subjects in general (Vilkuna 1989: 178-187, Hakulinen et al. 2004: § 1374). A similar restriction applies in French (Gaatone 1999: 103).

$\begin{array}{lllll}\text { a. Vain lapsi voi } & \text { esittää } & \text { jotain } \\ \text { only child can:3sG } & \text { suggest:INF-A } & \text { something } \\ \text { tällaista. (S24 2015) } & & \\ \text { like.this:PAR } & & \end{array}$

2 Ultimately, a semantic distinction between scalar and non-scalar uses may not be motivated (see e.g. Coppock \& Beaver 2014). I thank an anonymous referee for pointing this out.

3 In the examples, the negation and KuIN are in boldface, the E-focus in italics. S24 = Suomi2 4 corpus, $\mathrm{LA}=$ the dialect interview corpus..

4 Clear examples of vaIN placed like in example (6a) are extremely rare in the dialect corpora. 
b. Mitään tällaista ei voi anything like.this:PAR NEG.3SG can.CNG esittää kuin lapsi. suggest:INF-A KUIN child

Both a and b: 'Only a child can suggest something like this.'

The same is true for a non-subject in the Topic position and any element preceding this position. The negator often precedes the Topic position element, e.g. the object in (7a), but the latter still cannot be the E-focus $(7 \mathrm{c})$ :
a. Ei
tällaista
Voi
esittää
kuin lapsi.
NEG.3SG like.this:PAR can.CNG suggest:INF-A KUIN child 'Only a child can suggest something like this.'
b. *Ei kuin lapsi voi esittää tällaista. NEG.3SG KUIN child can.CNG suggest:INF-A like.this:PAR

Although the negator must precede the E-focus and the E-focus must come "late" enough, the clause is sometimes continued after it, especially in spoken language (8a). Normally, the E-focus follows the main verb, but as seen in (8b), this is not a strict requirement.

(8) a. ja / sitte "aamulla niin- ku se "äeti meni 'lypsylle niin 'and in the morning when mother went to milk'

$\begin{array}{llll}\text { ei } & \text { "lähtenyk } & \text { kun } & \text { "kahve'kupillinen } \\ \text { NEG.3sG } & \text { leave:PTCP } & \text { KUIN coffee:cupful } \\ \text { siitä } & \text { 'lehmästä } & \text { 'maitua (LA Ylikiiminki) } \\ \text { 3SG:ELA } & \text { cow:ELA } & \text { milk:PAR }\end{array}$

'only a cup of milk came off the cow.'

b. Energia on niin suuri asia että

'Energy is such a big issue that'

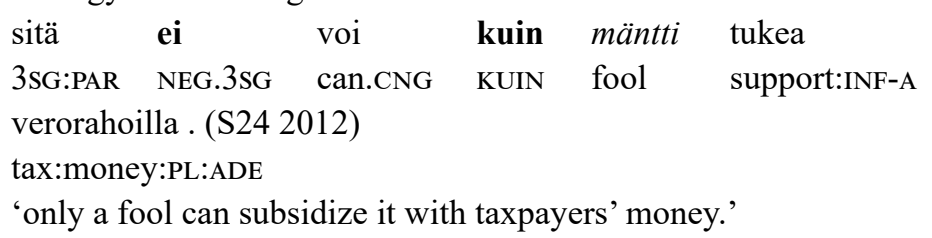


As can be observed, I treat the E-focus as a 'bona fide' clausal constituent. A clause involving the ENC is a simple clause, rather than, e.g., a clause combination where a conjunction (KUIN) introduces an elliptic part. The construction is peculiar, however, as KUIN divides the clause in two parts, which are in many cases incompatible with the generalizations that otherwise hold in the morphosyntax of Finnish negation.

\subsection{Negation}

The ENC clause is formally negated, but the E-focus remains outside the scope of negation. This is most clearly seen from the object case, which is genitive in (9), both in the formally negative ENC clause (9a) and in the formally affirmative clause with or without the particle vaIN (9b). Normally, clausal negation requires partitive case (10a) and rules out the genitive $(10 \mathrm{~b}) .^{5}$
a. En
ole lukenut
kuin
ensimmäisen luvun.
NEG:1SG be.CNG
read:PTCP
KUIN first:GEN
chapter:GEN
b. Olen lukenut (vain) ensimmäisen luvun.
be:SG1 read:PTCP only first:GEN chapter:GEN

Both a and b: 'I have read only the first chapter.'

(10) a. En ole lukenut ensimmäistä lukua.

NEG:1SG be.CNG read:PTCP first:PAR chapter:PAR

'I haven't read the first chapter.'
b. *En
ole lukenut
ensimmäisen
luvun.
NEG: 1 SG
be.CNG
read:PTCP first:GEN
chapter:GEN

Partitive object is also possible as an E-focus, but only in its unbounded sense, indicating e.g. imperfectivity or indefinite quantification (see Huumo 2010). This is the case in (11), where partitive is also the default marking for the object of the verb katsoa '(take a) look'.

5 More precisely, "genitive" should be understood as "non-partitive", for the object in affirmative clauses has nominative case when it is plural and in imperatives and certain impersonals. Note that many studies, especially before Hakulinen et al. (2004), use the label "accusative" for the object-marking genitive. 


(11) En $\quad$ ole
NEG:1SG be.CNG look:PTCP KUIN a:little first:PAR
lukua.
chapter:PAR
'I have only taken a (little) look at the first chapter.'

Like any negated clause, an ENC clause takes a partitive-marked object when the object is not the E-focus, such as asiaa in the pre-focus part (12).

\begin{tabular}{|c|c|c|c|c|}
\hline $\begin{array}{l}\text { En } \\
\text { NEG:1SG }\end{array}$ & $\begin{array}{l}\text { kertonut } \\
\text { tell:PTCP }\end{array}$ & $\begin{array}{l}\text { asiaa } \\
\text { matter:PAR }\end{array}$ & $\begin{array}{l}\text { kuin } \\
\text { KUIN }\end{array}$ & $\begin{array}{l}\text { joillekin } \\
\text { some:PL:ALL }\end{array}$ \\
\hline
\end{tabular}

Apart from object case, the nature of the ENC is also reflected in the use of negative and positive polarity items. Negative polarity items are used in the non-focus sections of the clause while the E-focus hosts positive items, such as the indefinite joillekin 'to some' in (12). A pair of examples illustrating this contrast is (6) above. In (6a), the situation is like in (12), but (6b) contains the corresponding negative polarity element mitään 'anything'.

As the E-focus need not be clause-final, it can be asked if it is the only part of the clause that exhibits affirmative polarity, i.e., if the clause continues in negative form after the E-focus. Corpus evidence is scarce and intuitions uncertain, but in the dialect corpus, clause continuations after the E-focus show both affirmative and negative orientation. The latter is the case in (13), where the negative polarity form of the additive clitic, i.e. 'either, even' is used. ${ }^{6}$

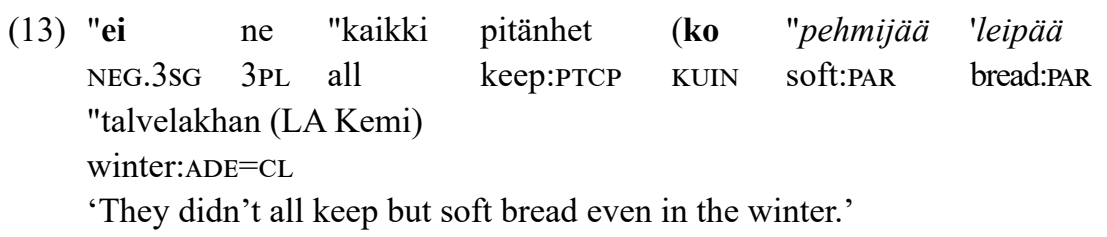

6 Example (13) cannot be translated with only, because the floating quantifier kaikki 'all' is in the scope of negation: 'not all'. This is unlike in French according to Gaatone (1999: 102). 
Taken as a simple transitive clause, then, an ENC clause is not easily seen as composed according to general rules. Another idiosyncrasy of the ENC is that it cannot be negated - there is no formally affirmative ENC or an ENC with two negators cancelling each other. This means that content such as 'I haven't read only the first chapter' can only be expressed by using the particle vaIN. This is unlike in French, where particles like pas are the main exponents of the negative meaning and the ne...que clause can be negated with pas (as in Félix ne boit pas que de l'eau 'Félix does not only drink water' (Gaatone 1991: 112)). In Finnish, the lack of the affirmative/negative opposition raises the question whether the ENC is negative or affirmative in meaning. Given the basic semantics of exclusion, which contains a negative component (see the discussion on (4)), it is not surprising that it raises polarity issues. We will return to negation in Section 3.

Before proceeding further, one more issue concerning the negativity of the ENC should be addressed: the construction can also be attested without formal negation when an implication of negation is evoked, which may happen in yes/no interrogatives. This seems to be rare but not altogether surprising, for the same type of situation also allows exceptions to partitive of negation and other negative polarity items. An example is (14); the question is strongly rhetorical, conveying 'this kind of thing can only happen in the US'?

(14) voiko tällaista tapahtua kuin jenkeissä? (S24 2008) can:3sG $=\mathrm{Q}$ like.this:PAR happen:INF-A KUIN States:INE

'Can this kind of thing happen anywhere but in the States?'

Instances like these make the formal description of ENC a challenge, as it cannot be straightforwardly tied to the formal exponents of negation like in (4). The same challenge is met by any description of Finnish negation-licenced phenomena, and I will not treat it here.

7 The ENC also occurs in the affective negation construction without an over negator (Kotilainen 2007, Vilkuna 2015: 481). 


\subsection{The syntactic contexts}

The ENC is almost exclusively instantiated in finite clauses. This follows from the fact that negation is largely a finite phenomenon in Finnish, being formed by a negative auxiliary that has no non-finite forms. However, ENC is attested in the negative (-mAttA) converb construction, where the infinitival form of the verb has abessive case (15) (Vilkuna 2015: 464-466, Hamunen 2018).

(15) ihmisiä jotka aikanaan on kasvattanut isoja lapsilaumoja 'people who in their time have raised lots of children'

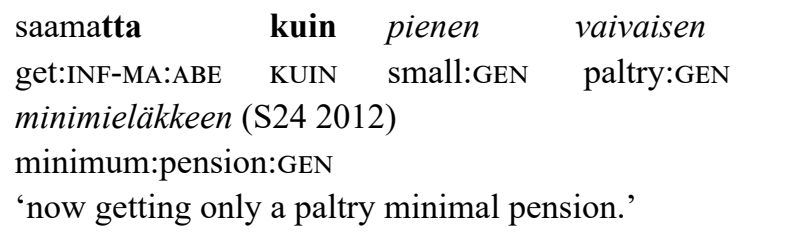

When the E-focus is inside a non-finite complement, negation is found in the "topmost", finite structure as in (16). Constituents of infinitival complements are generally affected by negation in other ways as well, i.e. object case marking and licensing of polarity items (Hakulinen et al. 2004: § 903).

$\begin{array}{lllll}\text { Yksittäisen } & \text { teoksen } & \text { ei } & \text { voi } & \text { olettaa } \\ \text { single:GEN } & \text { work:GEN } & \text { NEG.3SG } & \text { can.CNG assume:INF-A } \\ \text { kattavan } & \text { kuin } & \text { osan } & \text { sosiolingvistiikan } \\ \text { cover:PRCP:GEN } & \text { KUIN } & \text { part:GEN } & \text { sociolinguistics:GEN } \\ \text { teorioista } & j a \quad \text { tutkimuksellisista } & \\ \text { theory:PL:ELA } & \text { and } & \text { research:ADJ:PL:ELA } & \\ \text { lähestymistavoista. (Virittäjä 2019:137) } & & \\ \text { approach:PL:ELA } & & \end{array}$

'A single work cannot be assumed to cover more than a part of sociolinguistic theories and research approaches.'

That the ENC is a clausal construction means that its scope is a predication with a verb and its arguments and adjuncts. It occurs in practically all Finnish argument structures. According to my corpusbased observations, there is a fairly clear prototype, however. It is existential in a broad sense (Hakulinen et al. 2004: § 893-904), conveying 
that something is present in a location or in someone's possession. ${ }^{8}$ Example (2) illustrates the possessive clause type. Closely related to existentials are the so-called Quantifier clauses (Hakulinen et al. 2004: $\S 902-903)$, where a partitive argument denoting a set or mass is specified for number or size in a separate phrase (17).

\begin{tabular}{|c|c|c|c|}
\hline $\begin{array}{l}\text { Pakkastakaan } \\
\text { frost:PAR }=\mathrm{CL} \\
\text { joten ilma suosi }\end{array}$ & $\begin{array}{l}\text { ei } \quad \text { ollut } \\
\text { NEG.3SG be:PTCP } \\
\text { (S24 2012) }\end{array}$ & $\begin{array}{ll}\text { kuin } & \text { pari } \\
\text { KUIN } & \text { couple }\end{array}$ & $\begin{array}{l}\text { astetta, } \\
\text { degree:PAR }\end{array}$ \\
\hline
\end{tabular}

The large share of existentials and especially quantifier clauses among the ENC in the data points to the centrality of the scalar reading in the ENC.

In (18), I present examples from various other clause types: copular, with a nominal predicate as the E-focus (18a), intransitive with an oblique E-focus (18b), transitive with an adjunct E-focus (18c), and an infinitival complement as E-focus (18d).

$\begin{array}{lllll}\text { a. Luonnollisuus } & \text { ei } & \text { ole } & \text { kuin } & \text { markki } \\ \text { naturalness } & \text { NEG.3SG } & \text { be.CNG } & \text { KUIN } & \text { market } \\ \text { se EI takaa tuotteen terveellisyyttä tai hyödyllisyyttä. (S24 } \\ \text { 'Naturalness is only a marketing term, it does NOT guara } \\ \text { product is healthy or useful.' } \\ \begin{array}{lllll} & & & \\ \text { b. Ihmisen } & \text { kapasiteetti } & \text { ei } & \text { riitä } & \text { kuin } \\ \text { person:GEN } & \text { capacity } & \text { NEG.3SG } & \text { suffice } & \text { KUIN } \\ \text { yhteen } & \text { asiaan } & \text { kerrallaan. (S24 2016) } \\ \text { one:ILL } & \text { thing:ILL } & \text { time:ADE:3POSS }\end{array}\end{array}$

'Human capacity is only enough for one thing at a time.'

8 In the 433 ENC occurrences obtained from the LA dialect corpus, I have calculated that 192 or nearly $45 \%$ contain the verb olla 'be' in a broadly existential meaning. In addition, 21 of the 56 intransitive clauses with other verbs exhibit existential syntax. Although the proportion of the existential pattern in the whole corpus is not known, it is clearly lower than in the ENC subpart. The figures should be taken with caution, however, for the borders of the existential organization are vague in themselves (see Hakulinen et al. 2004: § 893) and, also because continuous speech often results in overlap structures and various disfluency phenomena that make many occurrences open to different interpretations. 


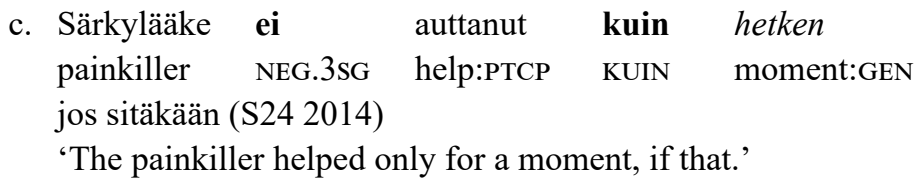

d. On ollut hirveä päivä,

'It's been an awful day,'

$\begin{array}{lccrl}\text { tästä } & \text { ei } & \text { voi } & \text { kuin } & \text { nousta ... (S24 2012) } \\ \text { here:ELA } & \text { NEG.3sG } & \text { can.CNG } & \text { KUIN } & \text { rise:INF-A } \\ \text { 'you can only move upwards from here... } & \end{array}$

Patterns like (18d) figure prominently among infinitival E-foci. The modal verb is in the scope of negation, and the action expressed by the infinitival clause is presented as inevitable ('can only') or minimally sufficient ('need only').

Finally, what happens if a finite verb is focused? With compound tenses, the main verb or verb phrase can be the E-focus (19). ENCs with simple finite verbs need further investigation, but a relatively wellrepresented type is the one in (20), expressing an escalating process of change. ${ }^{9}$

$\begin{array}{llllll}\text { sinä et } & \text { ole } & \text { kuin } & \text { kopioinut ja linkittänyt } \\ \text { 2SG NEG:2SG } & \text { be.CNG KUIN } \begin{array}{l}\text { copy:PTCP and link:PTCP } \\ \text { tietoa }\end{array} & \text { muista } & & \text { lähteistä, } \\ \text { information:PAR } & \text { other:PL:ELA } & \text { source:PL:ELA } & \end{array}$

mutta sinun asiapitoiset omat kirjoitukset todella vähissä ! (S24 2007) 'you have only copied and linked information from other sources, but your own informative writings have been really scarce!'

(20)
Lama ei kuin
syvenee . (S24 2016)
recession NEG.3SG
KUIN
deepen:3sG
'The recession only keeps deepening.'

9 Finnish does not use the verb 'do' as a support verb in the manner of the French Le bébé ne fait que pleurer 'The baby does nothing but cry' (O'Neill 2011: 180). As pointed out by an anonymous referee, there is another idiomatic construction for expressing escalating changes like (20), namely Lama sen $\boldsymbol{k} \boldsymbol{u}(\boldsymbol{i}) \boldsymbol{n}$ syvenee (see also Hakulinen et al. 2004: $\S 806)$. Here, the combination sen [3SG:GEN] + KUIN is rather opaque, but the dictionary NS (1963) (s.v. kuin) brings it together with meanings like 'as much as' or 'that amount which', e.g. säästät sen kun voit 'you save what (money) you can'. 
Finite E-foci are covered by the schematic description of the ENC in (4), but they seem to present a puzzle to the users: should the verb be in the normal personal form used in affirmative clauses, as expected from the E-focus, or in the connegative form as dictated by the negative auxiliary? Both forms occur in the corpora. Intransitive change verbs of the type in (20) seem to favour the person-inflected verb as in (21a), but there are also occurrences with the connegative form, at least when it is not the verb alone that is the E-focus, e.g. (21b).

(21) a. Ja palvelut eivät kuin huononevat. (S24 2014) and service:PL NEG:3PL KUIN worsen:3PL

'And services are only getting worse.'

b. On selvä, että

'It is clear, that'

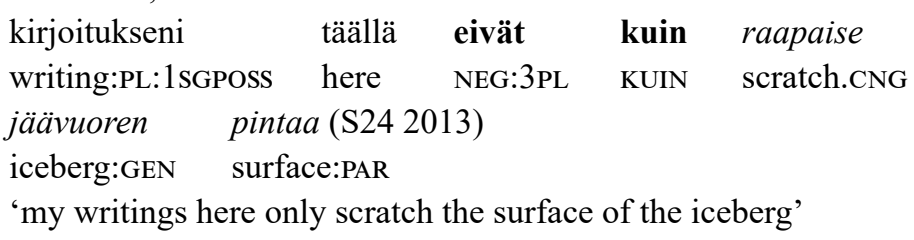

Verb-focusing ENC clauses sometimes come close to a pattern that is a separate construction with a conventional interactional meaning (Uusitupa 2017: 158-161). This construction consists of negation, KUIN and a verb or directional locative phrase and functions as an encouragement to take action: 'just go ahead'. If the action is indicated by a verb, the verb is typically in imperative or inifinitival form, but second person is also possible (22):

(22) [Advice for a participant in a difficult relationship]

Jos ei ole lapsia,

'If there are no children,'

$\begin{array}{llllll}\text { niin ei } & \text { kun } & \text { pistät } & \text { äijän } & \text { pihalle (S24 2012) } \\ \text { so NEG.3sG } & \text { KUIN } & \text { put:2SG } & \text { guy:GEN } & \text { out } \\ \text { 'just kick the guy out' } & & & \end{array}$

This construction is not a standard ENC, for the negator is not inflected in person whereas the main verb (pistät) is. Still, the pattern where the negator and KUIN are initial and adjacent is not reserved 
for the 'just go ahead' construction only, for the interviewee B in (23) clearly uses it in the exclusive meaning of the ENC in his answer to the interviewer's content question. As this speaker also uses the 'just go ahead' construction elsewhere, it can be hypothesized that the two have something in common. ${ }^{10}$

(23) [About preparations for a long fishing trip]

A: minkälaisija leipijä ne, kuletti sinne .

'What kind of bread did they carry with them?'

B: ei kur "ruisleipää 'vai / "pehemijää./

NEG.3SG KUIN rye:bread:PAR only soft:PAR

'Just rye bread, soft.'

'ei sitä "kovaa enner 'ruukattukkaa (sillo . (LA Salla)

'Hard bread was not customary anyway in those times.'

To summarize the discussion this far, we have seen that the ENC is a productive clausal construction of wide application but with restrictions stemming from its formal negativity. Its idiosyncratic properties, which make it a clearly distinguishable construction, are also connected to negativity.

\section{A brief comparison with the particle vaIN}

VAIN is the unmarked way of expressing exclusion of focus alternatives in Finnish, but it does other work as well, as a discourse marker (Duvallon \& Peltola 2017: 516-518) and as a conjunction (see section 1). I will not be concerned with these other functions but make some observations about the distribution of VAIN and the ENC. ${ }^{11}$ In

10 Non-inflected negators occur in Finnish (Vilkuna 2015: 461). The combination ei kun, often fused into $e i k u$, has a third use, namely as a repair marker (Haakana \& Visapää 2014), which must be separated from potential ENCs in the data. The repair marker is based on the use of the conjunction kun as the 'sondern' type conjunction in contrastive negation (Silvennoinen 2020), but probably from occurrences where ei and kun are adjacent, rather than the 'not X but Y' pattern (cf. Haakana \& Visapää 2014: 65).

11 The position of vaIn varies and is not taken into account here. The particle has two less frequent (near) synonyms, ainoastaan (derived from the adjective ainoa 'only') and pelkästään (from the adjective pelkkä 'bare'). In the time domain, the particle vasta is typically used, e.g. on vasta kuusivuotias 'is only six years old' (cf. the ENC example (5)). 
colloquial language, vAIN may co-occur with the ENC, taking a reinforcing role (24, see also (23)).

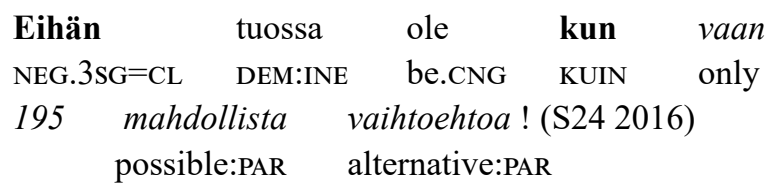

'There are only 195 possible alternatives [in what you presented]!'

The claim of the unmarkedness of VAIN is based on its frequency, which is clearly higher than that of the ENC. This difference is hard to quantify precisely, for the polyfunctionality of vaIN makes it often hard to decide whether a given occurrence of VAIN should be considered a focus particle and therefore comparable to the ENC. To illustrate the frequency relations, however, I compared ENC and vAIN in a prototypical scalar context, which is reasonably easy to handle, namely in connection with the verb 'be' and a numeric expression (see section 2.3). A search from one year of the Suomi24 corpus (2016, over 225 million word tokens) yielded 1641 occurrences of the ENC and 11298 occurrences of VAIN. ${ }^{12}$ Since the number of irrelevant cases is probably higher among the VAIN results, VAIN in this context can be estimated to be around 6 times as common as the ENC. My impression is that other types of foci would yield a bigger difference.

The following example is among the vaIN search results. Although most of these could be replaced with the ENC, (25) is in fact ambiguous between a pure focus particle use (i) and a discourse marker use (ii). Under the latter reading, which is the likely one in this rather argumentative case, vaIN is used much like English sentence-initial only or it's just that (cf. Duvallon \& Peltola 2017: 516-518). The ENC does not convey this reading.

12 These figures represent the uncontrolled results from two searches: for ENC, [lemma = "ei"] [pos != "Punct"] $\{0,3\}$ [lemma = "olla"] [word = "kuin"] [msd = ".*SUBCAT_ Card."” | word = "[0-9]*"] [word != "marjaa"] and for vaIN, [lemma = "olla"] [word = "vain"] [msd = ".*SUBCAT_Card.*”| word = " [0-9]* "]. Negated vaIN clauses or cases with both vAIN and the ENC are not excluded. In the first search, the word marjaa was excluded to exclude the common simile olla KUIN kaksi marjaa 'to be like two berries', i.e. 'to look alike'. The searches only cover the standard form of vaIN and do not cover all possible ordering variants, but the number of unwanted results seems low. 
(25) Eli yrität siis pelata kaikilla korteilla samaan aikaan ja aina kun joku vaihtoehto kumoutuu kokonaan tai osittain niin lasket sen varaan että jäljelle jää vielä vaihtoehtoja.

'So you are trying to play all your cards at the same time, and every time one alternative is turned over, you count upon the remaining alternatives.' Tuossa on vain pari ongelmaa : DEM:INE be.3sG only couple problem:PAR

(i) 'There are no more than a couple of problems [in what you wrote]:'

(ii) 'It's just that there are a couple of problems [in what you wrote]:' et todellisuudessa usko mihinkään vaihtoehtoon ja toisekseen mikään niistä vaihtoehdoista ei toimi . (S24 2016)

'you don't in fact believe in any of the alternatives, and second, none of the alternatives work.'

From the structural point of view, vaIN is more frequent than the ENC because it has more options, being just a particle that can be placed in various slots, even in negated sentences and in front of the subject. A further restriction of the ENC is that it can only have clausal scope, so that very narrow-scope exclusion must be expressed with VAIN. In (26), the focus of the particle is the phrase ' $€ 1500$ ' and the scope is the participial clause (here functioning as a referential NP). Vain 1500 euroa is translatable as 'as little as 1500 Euros' (see König 1999: 107-110). As shown in (26b), ENC takes the entire clause in its scope.

(26) a. tapsu6 taitaa liikkua vähän väärissä piireissä kun

'I guess [participant with alias] tapsu6 is moving in wrong circles, since'

ympärillä on vain 1500 euroa tienaavia.(S242016) around be.3SG only euro:PAR earn:PRCP:PL:PAR

(i) 'he has around him people earning only [as little as] $1500 €$ '

(ii) 'he has around him only people earning $1500 €$ '

b. Ympärillä ei ole kuin 1500 euroa around NEG.3sG be.CNG KUIN euro:PAR tienaavia.

earn:PRCP:PL:PAR

(ii), not (i)

Scope differences that are less directly structural sometimes surface when exclusion interacts with modals. The ENC only allows negation 
to take scope over the modal, whereas the negation implied by vaIN can have narrow scope. In the car leasing advertisement in (27a), this latter option is employed to present one type of action, driving, as a desirable possibility as opposed to other things one is obliged to carry out as a car-owner. This is not possible with the ENC, and (27b) simply conveys that all you can do with a car is to drive it.

(27) a. Uutta autoa ei tarvitse ostaa.

'You don't need to buy a new car.'

Sillä voi vain ajaa.

3SG:ADE can:3sG only drive:INF-A

'You can just drive it.' (Helsingin Sanomat, November 2, 2019.)

b. Sillä ei voi kuin ajaa.

SG3:ADE NEG.3SG can KUIN drive:INF-A

'You can only drive it.'

These differences between the ENC and VAIN in interaction with modals are connected to the fact that the ENC is overtly negative. The scope relations between the negation and the modal are the same in the ENC and other overt negation.

VAIN cannot be claimed to be synonymous with the ENC, even though its focus particle use conveys basically the same exclusive meaning. As different as VAIN and the ENC are structurally and in terms of distribution and origin, they share the property of being somewhat peculiar when it comes to polarity. The ENC licenses negative polarity elements (NPIs) in the non-focus part of the clause by virtue of its formal negativity, while vAIN normally requires positive polarity elements; recall the contrast between jotain 'something' in (6a) and the NPI mitään 'anything' in (6b) in section 2.1. On the other hand, there are contexts in which even vaIN licences NPIs (Hakulinen et al. 2004: $\S 1639$ ). Both ENC and vaIN clauses exhibit an ambivalence in that they simultaneously give a positive and a negative message. In the case of 'I have only read the first chapter' (example (9): En ole lukenut kuin / Olen lukenut vain ensimmäisen luvun), these can be paraphrased as 'I have read the first chapter' and 'I haven't read the whole book'. In the literature on exclusive focus particles, there has been much discussion on which of these messages is the truth-functional content and which is 
an implication, and whether the implication is a presupposition or something else (see Sudhoff 2010: 48-51 for an overview). The best-known presuppositionhood test, viz. that presuppositions are preserved when clausal polarity is changed, cannot be tested in the case of the ENC, which has no polar alternative. In this paper, I have chosen to overlook these distinctions. It is obvious that both the positive and the negative message are involved in both types of expressions.

\section{The ENC in a construction network}

\subsection{Comparative constructions}

We have seen how the ENC unifies with any clausal structure. The same is true for the comparative KUIN construction (here $\mathrm{CmpC}$ ), which consists of a word licensing a KUIN phrase followed (not necessarily immediately) by the KUIN phrase, the standard of comparison. ${ }^{13}$ The licensors include not only degree comparison such as morphological comparative but also words like sama 'same' and the word in focus here, тии 'other', when these look forward, i.e. find their interpretation in what is said following them. Regarding its form, the ENC thus looks like a simple clausal negation plus a $\mathrm{CmpC}$ but lacking a licensor for the KUIN phrase.

The ENC inherits some of the CmpC's features, but not all its structural options. Typically, the KUIN phrase is similar in CmpC and ENC: the particle and a single phrase. However, in the $\mathrm{CmpC}$, the KuIN phrase often has a role that "doubles" an expressed participant in the clause (the subject joku muu and Mikko in (28)). The KuIN phrase in the CmpC can also be more complex than one phrase, such as the Gapping structure in (29a) resulting from parallelism between pairs of comparands, or a finite clause (29b). KuIN phrases such as those in (29) do not occur in the ENC.

13 The particle KUIN is also used in similes, e.g. ei ole kuin postikortti 'is not like a postcard' (Heinonen 2010). Examples like this are in principle ambiguous between ENC and a simile, but as Heinonen (2010: 356, 360, footnote 14) shows, similes favour affirmative contexts. 
(28) Sen

Sen teki joku muu kuin Mikko. 'It was done by someone else than Mikko.'

\begin{tabular}{|c|c|c|c|c|}
\hline Älä & tee & samaa & virhettä & kuin \\
\hline NEG.IMPR & make.CNG & same:PAR & mistake:PAR & KUIN \\
\hline minä & kerra & & & \\
\hline $1 \mathrm{sG}$ & time: & & & \\
\hline
\end{tabular}

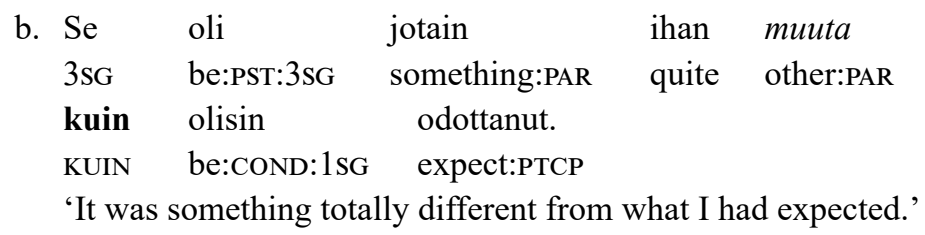

A further difference between the two constructions is that the KUIN phrase in CmpC allows negative polarity items, such as the clitic $-k A A n$ 'either, even' in the scope of negation in (30). In the ENC, the E-focus is not in the scope of negation.
(30) $\mathrm{Ei}$ minun tarvitse tehdä
NEG.3SG I:GEN MOD.CNG do:INF-A
mitään $\quad$ muuta kuin nytkään. (S24 2016)
'I don't have to do anything else but (what I do) even now.'

Comparative constructions are typically seen as involving massive ellipsis, especially in generative treatments (Lechner 2018). Putting other comparative ellipsis aside, a moderate description of ENC could be that there is a silent licensor with properties of the comparative words mentioned above (for French, e.g. O’Neill 2011, Homer 2015). On this account, the ENC would just be an even more elliptic CmpC. But what should the silent element be? A generally accepted requirement for such elements is unique recoverability (see Authier 2020). Given the range of possible scalar and non-scalar readings of the ENC, however, several different elements can be proposed, even in the same context (cf. Gaatone 1999: 109-114). These include muи 'other' in its different case forms (31a), adverbs derived from muи (31b), and in scalar cases, adverbs measuring amount, distance or time (31a-c). 


$\begin{array}{lllll}\text { (31) a. } & \text { En } & \text { lukenut } & \text { muuta / enempää } \\ & \text { NEG.3SG } & \text { read:PTCP } & \text { other:PAR more:PAR } \\ \text { kuin } & \text { ensimmäisen } & \text { luvun. } \\ & \text { KUIN } & \text { first:GEN } & \text { chapter:GEN }\end{array}$

'I didn't read anything else / more than the first chapter.'

b. En käynyt muualla/ kauempana kuin Raahessa. NEG.3SG visit:PTCP other:ADV farther KUIN Raahe:INE 'I didn't go elsewhere / any farther than Raahe.' $\begin{array}{llllll}\text { c. En } & \text { ollut } & \text { siellä } & \text { enempää/ kauempaa } & \text { kuin } \\ \text { NEG.3SG } & \text { be:PTCP } & \text { there } & \text { more:PAR } & \text { longer:PAR } & \text { KUIN }\end{array}$ tunnin. hour:GEN 'I wasn't there for any more / any longer than an hour.'

All this makes silent comparative licensors as part of the syntax of the ENC an awkward solution compared to a constructional treatment where the meaning is described in the semantic pole of the construction as sketched in (4). Note that in (4), the meaning is abstract, not tied to any particular lexical item. Still, especially in colloquial language, the word $m u и$ has a special role in the constructionalization of the ENC, as will be seen in the following section.

\subsection{From muи 'other' to particle muuta}

Muu is a pronoun-like element that occurs as an independent nominal head, as a noun modifier and in a handful of derived adverbs (such as munalla 'elsewhere' in (31b)). This section concentrates on the independent тии in singular partitive form, muиta. Like any partitive NP, this word form can act as the object (32a), the existential first argument (32b) and the predicate complement function (32c) in the clause. Under negation, it often occurs with the indefinite quantifier mitään.

$\begin{array}{llll}\text { En } & \text { lukenut } & \text { (mitään) } & \text { muuta. } \\ \text { NEG:1SG } & \text { read:PTCP } & \text { anything:PAR } & \text { other:PAR } \\ \text { 'I didn't read anything else.' } & \end{array}$


b. Minulla ei ole (mitään) muuta. 1SG:ADE NEG.3SG be.CNG anything:PAR other:PAR 'I don't have anything else.'

c. Hän ei ole (mitään) muuta kuin pelle. 3SG NEG.3SG be.CNG anything:PAR other:PAR KUIN clown 'S/he is nothing else but a clown.'

Looking at occurrences of the combination muuta KUIN in dialectal speech and informal writing reveals a more varied picture. The combination also occurs in contexts that do not otherwise allow a partitivemarked complement or where muuta does not match a potential partitive-marked role. The examples in (33) are a selection of these.

\begin{tabular}{|c|c|c|c|c|}
\hline En & laita & viestiä & muuta & kun \\
\hline NEG.3SG & put.CNG & message:PAR & other:PAR & KUIN \\
\hline tuolle & yhdelle & parhaalle & kaverille (S2 & 4 2012) \\
\hline DEM:ALL & one:ALL & best:ALL & friend:ALL & \\
\hline
\end{tabular}

b. Kiviniemi nyt ei ole onnistunut muuta $<$ name $>$ PTL NEG.3SG be.CNG manage:PTCP other:PAR

kuin sotkemaan asioita. (S24 2012)

KUIN mess:up:INF-MA thing:PL:PAR

'Kiviniemi has only managed to mess things up.'

c. Fundamentalisti ei voi ajatella muuta fundamentalist NEG.3sG can.CNG think:INF-A other:PAR kuin mustavalkoisesti. (S24 2012)

KUIN black:white:ADV

'A fundamentalist is only able to think in a black-and-white manner.'

d. Hitlerin ns. voitto ei olisi Hitler:GEN so.called victory NEG.3sG be:COND.CNG munta kuin other:PAR KUIN 'Hitler's so-called victory would only have' pitkittänyt vääjäämätöntä lopputulosta (S24 2016) delay:PTCP inevitable:PAR end:result:PAR 'delayed the inevitable final outcome' 
Such occurrences indicate that the form muuta is essentially a linking element, an unanalysable particle rather than a word with referential meaning. Note also that the negative indefinite mitään is not naturally added to the munta KUIN expression in these cases. Another indication of this decategorialization of muuta is that it also occurs with KUIN and numeral or other measure phrase E-foci where not all 'other' but only higher values are excluded:
a. 'ei se 'tiämmä 'sais- olla muuta ko NEG.3SG 3SG PTL MOD.CNG be:INF-A other:PAR KUIN "seittämänkyntä 'prosenttii/ 'vesi / kuuma. (LA Noormarkku) seventy percent water hot
'As far as I know, it should not be more than [should be only] seventy percent [sic], the water in temperature.'

b. Se puhe ei kestä muuta kuin 1-2 päivää, 3SG talk NEG.3SG last.CNG other:PAR KUIN day:PAR ei niillä puheilla ole mitään katetta. (S24 2016)

'That talk won't last more than [will last only] 1-2 days, such talk has no credibility.'

The loss of referentiality of muи in spoken dialects in connection with KUIN phrases was already observed in two dialect syntactic overviews at the turn of the 19th century, Latvala (1895) and Kannisto (1902). These authors investigated western Finnish dialects in certain parishes in the provinces Satakunta and Häme. Both present ample data with muuta KUIN in a role analogous to (33), as well as with the ENC. Kannisto (1902: 262-265, 272-273) sketches a continuum from a referential (potential object) muuta to unstressed muuta that he assumes to be a conjunction. ${ }^{14}$ Latvala (1895: 74-75) points out that either of the words muи or KUIN (i.e. kun) can be omitted from the combination NeG muи KUIN 'not other than'. In the present terms, the choice of muuta instead of KUIN forms a dialectally restricted type of ENC. Two examples are given in (35).

14 There is a path from this situation to the adversative coordinator mutta 'but'. The accepted etymology of the Finnish mutta is also based on muи (SSA 1995 s.v. mutta), but this is an older development than the process observed by Kannisto. 
(35) a. Ei

$$
\text { muarill om muuta }
$$

NEG.3SG old.woman:ADE be.CNG other:PAR

yks lehmä (Kannisto 1902: 263)

one cow

'The old woman has only one cow.'

b. [While managing a fishing net]

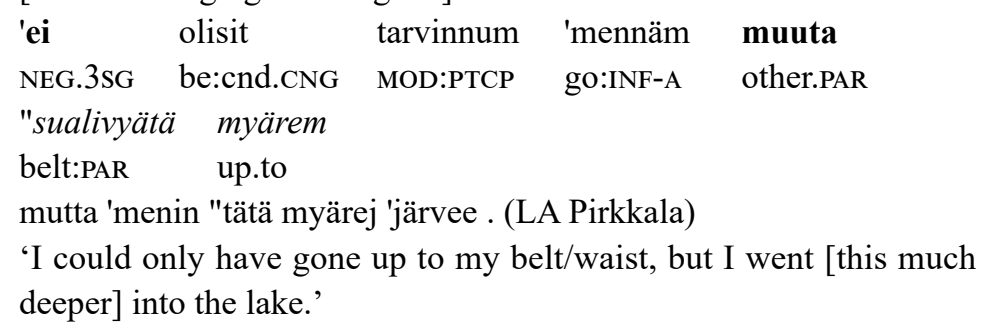

The options of omitting either тии or KUIN are not enough; the two can also be fused into a form like muukko in (36).

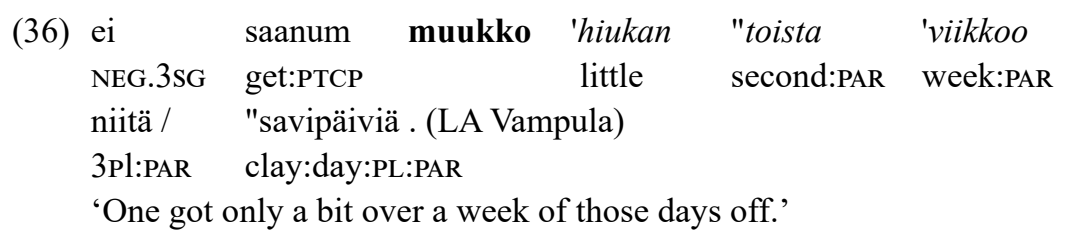

The phenomena discussed in this section are realizations of a general 'NeG OTHER THAN' schema modelled after the CmpC, but display a tendency towards simplification that we will return to in Section 5. This process has had the most varied outcome in the western Häme and Satakunta areas; the option of the sole muuta has remained a narrow areal phenomenon while the ENC is known across the dialect areas. At least partly comparable simplifications seem to have led to the ne...que construction in French (Moignet 1973 cited in Authier 2020). The difference in the outcome appears to be mainly the result of the differences in the negation systems of Finnish and French.

\subsection{Exceptive expressions}

The French ne...que construction is often called exceptive (e.g. O’Neill 2011, Homer 2015, Authier 2020; see Gaatone 1999: 101 for the various terms). The term seems to suggest a way of indicating 
exceptions to generalizations (e.g. von Fintel 1993). The Finnish ENC has clear connections to exceptive constructions, and many instances of ENC can also be read as exceptive in meaning. Despite such overlaps, I want to keep exceptives and the ENC separate. The dedicated exceptive marker in Standard Finnish is the particle paitsi (Hakulinen et al. 2004: $\S 1110) .{ }^{15}$ In this section I look at the borderlines between the ENC and related patterns with an exceptive reading: paitsi, muи KUIN and a more marginal variant, mikään KUIN. Our main interest is on the combination muuta KUIN, which is an alternative to paitsi in negative contexts.

Exceptives are not in themselves restricted to negative environments and are in this sense a broader phenomenon than the ENC. The essential condition for the exceptive reading is that some kind of generalization is made. Affirmative sentences with an exceptive phrase often contain a universal quantifier, e.g. kaikki paitsi 'everything except'. I will only be concerned with exceptive phrases in the clause-final position and with negated clauses. As seen in (37), paitsi can be replaced by muuta KUIN, at least in colloquial language.

$\begin{array}{llllll}\text { a. Mikään ei } & \text { ole } & \text { pysyvää } & \text { paitsi } & \text { muutos. } \\ \text { anything NEG.3SG } & \text { be.CNG } & \text { constant:PAR } & \text { except } & \text { change } \\ \text { 'Nothing is constant except change' } & & \\ & & & & \\ \text { b. Mikään ei } \quad \text { ole } & \text { varmaa } & \text { munta } & \text { kuin } \\ \text { anything NEG.3SG be.CNG } & \text { certain:PAR } & \text { other:PAR } & \text { KUIN } \\ \text { epävarmuus. (S24 2012) } & & & \\ \text { uncertainty } & & & \\ \text { 'Nothing is certain except uncertainty.' } & \end{array}$

Concerning the ENC and negated clauses with an exceptive phrase, there are a few crucial differences. First, the exceptive phrase can "double" an argument or adjunct in the clause, in the manner of the KUIN phrase in the CmpC. Thus in (37a), muutos 'change' is parallel

15 The category of paitsi is indeterminate (Hakulinen et al. 2004: § 708). Paitsi can start a clause, often together with the complementizer että like in the English except that. This is the main use of paitsi among the few occurrences in the LA dialect corpus (cf. Ikola, Palomäki \& Koitto 1989: 65-66). Many paitsi phrases are truncated in the manner of the comparative KUIN phrases, and this is the type most relevant to the ENC. Paitsi also functions as an adposition as well as a coordinator (paitsi... myös 'except... also'). 
with the subject mikään (an indefinite in the scope of negation). This parallelism is not a property of the ENC. Second, literal exceptives are not used in scalar exclusion; for example, paitsi does not correspond in meaning to muuta KUIN in (34).

Third, while the ENC is there to negate the alternatives of a clausal element that is involved in the current predication, exceptives seem to operate on a completed clause and add a restriction to it, i.e. "cancel" a part of the predication, in the case of (37), the universal predication 'nothing is constant/certain'. Since adjunct KUIN phrases are in principle optional extensions of the clause, they are generally amenable to an exceptive reading. The result is that the ENC and the exceptive overlap in cases like (38).
(38) a. En käynyt ulkona paitsi/ muuta kuin öisin. NEG:1SG visit:PTCP out except other:PAR KUIN nightly 'I didn't go out except at night.'

\section{b. En käynyt ulkona kuin öisin. \\ 'I didn't go out except at night' or 'I only went out at night'.}

The difference has to do with information structure. In the ENC, the E-focus is at the same time the information focus or included in it (in the sense of Lambrecht 1994). In (38b), the focus is öisin 'at night', i. e. the time when I went out, whereas the focus in (38a) is 'did not go out', supplemented with the exception. This is a rather subtle difference that may not always be testable or even relevant, but sometimes overlapping readings are resolved by the context. In (39), the E-focus confirms the interviewee's answer to a question about the location of markets in the region. The interviewee first answers by naming a nearby town and then, after admitting that some people may have gone elsewhere, excludes alternatives to the first-named town for his own part. There is no implication that the interviewee might not have gone to market at all or that going to Raahe might be an exception. Therefore, (39) can be classified as an instant of ENC. 
(39) A: misäs täältä markinoilla käytii .

'Where did people/you go to market from here?'

B: "Raahesa / 'Raahem 'markkinoilla sitä 'käyttii . / 'kävi kain ne "nuo "hevoskauppiaat 'Oulusa ja 'Kokkolasa / ja 'Kalajoella

'In Raahe, people/we went to the Raahe market. I guess the horse dealers went to Oulu and Kokkola and Kalajoki ‘

$\begin{array}{lllll}\text { vai } & \text { em } & \text { "min- ook } & \text { 'käynym } & \text { 'markkinoilla } \\ \text { but } & \text { NEG:1SG } \quad 1 \text { SG } \quad \text { be.CNG } & \text { visit:PTCP } & \text { market:PL:ADE } \\ \text { ko } & \text { "Raahesa } & \text { (LA Pyhäjoki) } & & \\ \text { KUIN } & \text { Raahe:INE } & & \\ \text { 'but } & & & \end{array}$

'but I have only been in Raahe to market.'

In summary, there are good reasons to keep the ENC apart from exceptive constructions, despite the overlaps. I will finish this section by pointing out yet another pattern that can be called exceptive, viz. the use of KUIN following the negated indefinite mikään 'anything'.

$\begin{array}{lllll}\text { Elämässäni } & \text { ei } & \text { ole } & \text { mitään } & \text { kuin } \\ \text { life:INE:1sGPOSS } & \text { NEG.3SG be.CNG } & \text { anything:PAR } & \text { KUIN } \\ \text { koulu ja } & \text { koti.(S24 2013) } & & \\ \text { school and } & \text { home } & & \end{array}$

'I don't have anything but school and home in my life.'

The existence of this pattern, which lacks the word muu, was only revealed to me by the corpus data. The pattern is far from common but occurs in the Suomi24 corpus with the approximate frequency of twenty per year; it is too persistent to be taken as just an accidental omission of $m u и .{ }^{16} \mathrm{I}$ have also come across a handful of potential examples in the LA dialect corpus. Formally, (40) can be read to express the exception 'apart from school and home' to the claim 'my life is empty', but an ENC reading is not far. I will take this pattern into account when considering the role of the ENC among ways of expressing exclusion in the following section.

16 Native speakers I have consulted have considered the pattern somewhat odd but not unheard of. 


\section{Discussion: implicitness and explicitness in exclusion constructions}

By way of summary, this section looks at the ENC as a member of a network (Diessel 2019) of what could be called exclusion constructions, constructions expressing that a predication applies to element $e$ in a clause and does not apply to elements that are not $e$ but are comparable to $e$, i.e. the alternatives to $e$. We can start by distinguishing implicit and explicit strategies of expression. Implicit strategies accomplish the exclusion without overt negation, like the focus particle vaIN. Explicit strategies involve overt negation and whatever words the language in question has for 'other', 'than' and the complement of 'than', as discussed in Section 4. The patterns can also be placed in a scale like (41) using a simple example, viz. that the only place visited by the interviewee was Raahe.

\begin{tabular}{|c|c|c|c|c|}
\hline \multicolumn{2}{|c|}{$\begin{array}{l}\text { Haastateltava ei } \\
\text { interviewee NEG.3sG } \\
\text { 'The interviewee didn't go' }\end{array}$} & $\begin{array}{l}\text { käynyt } \\
\text { visit:PTCP }\end{array}$ & & \\
\hline \multicolumn{5}{|c|}{ 'The interviewee didn't go' } \\
\hline a. missään, & paitsi / & muuta & KUIN & Raahessa. \\
\hline anywhere & except & other:PAR & KUIN & Raahe:INE \\
\hline $\begin{array}{l}\text { b. (missään) } \\
\text { anywhere }\end{array}$ & & $\begin{array}{l}\text { muualla } \\
\text { other:ADV }\end{array}$ & KUIN & Raahessa \\
\hline c. missään & & & KUIN & Raahessa. \\
\hline d. & & [muuta & KUIN] & Raahessa \\
\hline 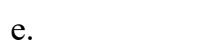 & & & KUIN $\sim$ muuta & Raahessa \\
\hline
\end{tabular}

(41a) represents an exceptive organization, where the paitsi/muuta KUIN phrase restricts the predication 'the interviewee didn't go anywhere'. In (b), the focus falls on the locative form of muи, 'elsewhere' (or 'otherwhere'), together with its complement phrase. I place the marginal pattern missään KUIN tentatively in (41c). In (d), 'other' is not locative but reduced to a part of the exclusion marker, i.e. the particle muuta, and (e) is an ENC with KUIN or the dialectal muuta. Note that muuta KUIN appears in two separate rows in (41).

(41) is essentially a scale of reduction. It is probable that some parts of this scale have had a role in the development of the Finnish ENC, i.e. that reduction in explicitness is part of its history. While people are likely to connect the ENC to some of the more fully spelled out 
constructions, the ENC is not one of those constructions; with its idiosyncratic properties, it is entrenched enough to be an independent member of the Finnish construction network. Support for the independent status of the ENC also comes from its scalar uses with numeral and other measure-phrase E-foci. As we saw, they are expected to associate with scalar expressions like 'more' rather than with the word muu 'other'. Still, they also occur with the reduced muuta in the combination muuta KUIN (type 41d), as seen in (34) above. This makes muuta KUIN rather central in my claim. If there is a uniquely recoverable silent element in the ENC, it is the invariant muuta. A more viable alternative in the present framework is to add muиta as an optional element in the ENC and include it in the formulation in (4). This issue is in need of further, probably experimental investigation, however.

The scale in (41) is inspired by Homer's (2015) ellipsis-based treatment of the French ne...que. Homer also points out a difference between ENC and the more explicit variants, concerning the affirmative inference that accompanies exclusion statements, namely that the predication holds for the E-focus. In (42), following Homer, a context is set up that explicitly questions the inference, i.e. that the interviewee visited Raahe. The ENC (42a, marked \#) is unexpected in this context while the more explicit variant in (42b) with muualla 'elsewhere' is possible.

(42) En tiedä kävikö haastateltava Raahessa, mutta sen tiedän että

'I don't know if the interviewee went to Raahe, but I do know that'

a. \#hän ei käynyt kuin Raahessa. [ENC, =41e]

b. hän ei käynyt muualla kuin Raahessa. [=41 b] 'he didn't go anywhere else than Raahe.'

That the affirmative implication is stronger in the ENC is no mystery in itself. The ENC does not contain any linguistic material that could receive prosodic prominence and be understood as the focus of negation. Such material is spelled out by the word munalla 'elsewhere' in (42b).

\section{Conclusion}

This paper has argued for an Exclusive-Negative Construction, ENC, as a part of Finnish grammar in the constructional framework. The ENC is similar to the French ne...que construction but differs from it at many 
points where Finnish and French grammar differ, especially in the way negation is expressed in the two languages. The fact that the Finnish ENC is formally negated (except for restricted environments) is behind many of the properties of the construction, its syntactic restrictions and its scope-related differences from expressions with the focus particle vaIN.

The constructional description is quite simple in many ways. The ENC clause is taken to be a simple clause with special properties, whose peculiarity, the division into a negative and an affirmative part, is taken as a property rather than explained away. Another simplification is that there is no need to problematize the category of the word KUIN or the invariant muuta that sometimes accompanies it - they are just items belonging to a construction - nor is there any need to endow them with semantics that they do not have elsewhere. On the other hand, the construction relies on existing building blocks from other parts of the grammar, such as the morphosyntax of negation and comparative constructions. It participates in a network of various ways of expressing exclusion.

Some important questions still remain. Patterns of exclusion seem to have a tendency towards reduction; why is this so, and can it be explained by the semantics and pragmatics of negation? It can also be asked what regulates the choice between the ENC and the much simpler way of excluding alternatives, using vaIN. Again, an obvious starting point to approach this issue is the negative form of the ENC, for as stated by Givón (1978) and numerous later studies, negation and affirmation are known not to be pragmatically equal in discourse. ENC can be assumed to be especially suitable in interactional contexts where a negative statement is relevant. However, it is not easy to extend this view to all occurrences, especially as the vaIN alternative also arguably contains a negative meaning component.

\section{Acknowledgements}

I would like to thank two anonymous referees for insightful remarks and Outi Duvallon for her generous help with the French data (the remaining mistakes are mine). Many thanks are also due to all the organizers and participants of the workshops called On milking grammar over the years. My key examples (1) trough (3) are meant to keep in mind this great tradition. 


\begin{abstract}
Abbreviations
1, 2, 3 - persons, ABE - abessive case, ADE - adessive case, ADJ adjective derivation, ADV - adverb derivation, ALL - allative case, $\mathrm{CL}$ - unspecified clitic particle, CNG - connegative, COND - conditional mood, DEM - demonstrative, ELA - elative case, GEN - genitive case, ILL - illative case, IMPR - imperative mood, INE - inessive case, INF-A $A$-infinitive, INF-MA $-m A$-infinitive, MOD - modal verb, NEG - negative auxiliary, PAR - partitive case, PL - plural, POSS - possessive suffix, PRCP - present participle, PRS - present tense, PST - past tense, PTCP past participle, PTL - unspecified discourse particle, Q - interrogative clitic, SG - singular
\end{abstract}

\title{
Transcription (dialect examples):
}

, /, // short and longer break, respectively

", ' $\quad$ stronger and weaker stress, respectively

( unclear pronunciation

\section{Corpora}

LA = Turun yliopisto, kieli- ja käännöstieteiden laitos \& Kotimaisten kielten keskus (1985). Lauseopin arkiston murrekorpuksen Helsinki-Korp-versio [tekstikorpus]. Kielipankki. Retrieved from http://urn.fi/urn:nbn:fi:lb-2016040702.

Suomi24 $=$ The Suomi 24 Sentences Corpus (2017H2) [text corpus]. Kielipankki. Retrieved from http://urn.fi/urn:nbn:fi:lb-2019021102.

\section{References}

Authier, Marc. 2020. On the comparative analysis of French (ne)...que exceptives. Probus 32(1). 1-54. https://doi.org/10.1515/probus-2019-0006.

Coppock, Elizabeth \& David I. Beaver 2014. Principles of the exclusive muddle. Journal of Semantics 31(3). 371-432. https://doi.org/10.1093/jos/fft007.

Dekydspotter, Laurent Pierre Aimeé. 1993. The syntax and semantics of the French ne... que construction. In Utpal Lahiri \& Adam Wyner (eds.), Proceedings from Semantics and Linguistic Theory 3, 38-56. Ithaca, N. Y.: Cornell University.

Diessel, Holger. 2019. The grammar network: How linguistic structure is shaped by language use. Cambridge: Cambridge University Press. https://doi.org/10.1017/ 9781108671040 . 
Duvallon, Outi \& Rea Peltola. 2017. Voimadynaaminen vaan. Odotusten, intentioiden ja kerrottavuuden partikkeli. Virittäjä 121(4). 500-533. https://doi.org/10.23982/ vir.58864.

Fintel, Kai von. 1993. Exceptive constructions. Natural Language Semantics 1(2). 23-148. https://www.jstor.org/stable/23752096.

Fried, Mirjam. 2015. Construction grammar. In Artemis Alexiadou \& Tibor Kiss (eds.), Syntax. Theory and analysis. An international handbook, vol. 2, 974-1003. Berlin/ Munich/Boston: De Gruyter Mouton. https://doi.org/10.1515/9783110363708.

Gaatone, David. 1999. Réflexions sur la syntaxe de 'ne...que'. In Marc Plénat, Michel Aurnague, Anne Condamines, Jean-Pierre Maurel, Christian Molinier \& Claude Muller (eds.), L'emprise du sens: Structures linguistiques et interprétations. Mélanges de syntaxe et de sémantique offerts à Andrée Borillo par un groupe d'amis, de collègues et de disciples, 101-115. Amsterdam: Rodopi.

Givón, Talmy. 1978. Negation in language: Pragmatics, function, ontology. In Peter Cole (ed.), Syntax and semantics. Volume 9: Pragmatics, 69-112. New York: Academic Press.

Goldberg, Adele E. 1995. Constructions: A construction grammar approach to argument structure. Chicago: University of Chicago Press.

Goldberg, Adele E. 2006. Constructions at work: The nature of generalization in language. Oxford: Oxford University Press. https://doi.org/10.1093/acprof: oso/9780199268511.001.0001.

Goldberg, Adele E. 2013. Constructionist approaches. In Thomas Hoffmann \& Graeme Trousdale (eds.), The Oxford handbook of construction grammar, 16-331. Oxford: Oxford University Press. https://doi.org/10.1093/oxfordhb/9780195396683.001.0001.

Goldberg, Adele E. \& Florent Perek. 2018. Ellipsis in construction grammar. In Jeroen van Craenenbroeck \& Tanja Temmerman (eds.), The Oxford handbook of ellipsis, 188-204. Oxford: Oxford University Press. https://doi.org/10.1093/ oxfordhb/9780198712398.013.8.

Haakana, Markku \& Laura Visapää. 2014. Eiku - korjauksen partikkeli? Virittäjä 118(1). 41-71.

Hakulinen, Auli, Maria Vilkuna, Riitta Korhonen, Vesa Koivisto, Tarja Riitta Heinonen \& Irja Alho. 2004. Iso suomen kielioppi. Helsinki: Suomalaisen Kirjallisuuden Seura. https://scripta.kotus.fi/visk/.

Hamunen, Markus. 2018 matтA-rakenteen kognitiivista semantiikkaa. Virittäjä 122(3). 356-386. https://doi.org/10.23982/vir.64471.

Heinonen, Tarja Riitta. 2010. Kuin-vertaukset. Virittäjä 114(3). 348-373.

Herlin, Ilona. 1998. Suomen kun. Helsinki: Suomalaisen Kirjallisuuden Seura.

Hilpert, Martin. 2014. Construction grammar and its application to English. Edinburgh: Edinburgh University Press.

Hoffmann, Thomas. 2013. Abstract phrasal and clausal constructions. In Thomas Hoffmann \& Graeme Trousdale (eds.), The Oxford handbook of construction grammar, 307-328. Oxford: Oxford University Press. https://doi.org/10.1093/oxfo $\mathrm{rdhb} / 9780195396683.013 .0017$. 
Homer, Vincent. 2015. Ne... que and its challenges. In Ulrike Steindl, Thomas Borer, Huilin Fang, Alfredo García Pardo, Peter Guekguezian, Brian Hsu, Charlie O'Hara $\&$ Iris Chuoying Ouyang (eds.), Proceedings of the 32nd West Coast Conference on Formal Linguistics, 111-120. Somerville, MA: Cascadilla Proceedings Project. https://www.lingref.com/cpp/wccfl/32/.

Huumo, Tuomas. 2010. Nominal aspect, quantity, and time: The case of the Finnish object. Journal of Linguistics 46(1). 83-125. https://doi.org/10.1017/ S0022226709990223.

Ikola, Osmo, Ulla Palomäki \& Anna-Kaisa Koitto. 1989. Suomen murteiden lauseoppia ja tekstikielioppia. Helsinki: Suomalaisen Kirjallisuuden Seura.

Kannisto, Artturi. 1902. Lauseopillisia havaintoja läntisen Etelä-Hämeen kielimurteesta (Suomi 20). Helsinki: Suomalaisen Kirjallisuuden Seura.

Kotilainen Lari. 2007. Kiellon lumo (Suomi 193). Helsinki: Suomalaisen Kirjallisuuden Seura.

König, Ekkehard. 1991. The meaning of focus particles. A comparative perspective. London/New York: Routledge.

Lambrecht, Knud. 1994. Information structure and sentence form. Cambridge: Cambridge University Press.

Latvala, Salu. 1895. Lauseopillisia havaintoja Luoteis-Satakunnan kansankielestä (Suomi 12). Helsinki: Suomalaisen Kirjallisuuden Seura.

Lechner, Winfried. 2018. Comparative deletion. In Jeroen van Craenenbroeck \& Tanja Temmerman (eds.), The Oxford handbook of ellipsis, 624-657. Oxford: Oxford University Press. https://doi.org/10.1093/oxfordhb/9780198712398.013.27.

Moignet, Gérard. 1973. Les signes de l'exception dans l'histoire du français. Geneva: Droz.

NS = Matti Sadeniemi (toim.). 1963. Nykysuomen sanakirja. Porvoo, Helsinki: WSOY.

O'Neill, Teresa. 2011. The syntax of ne...que exceptives in French. University of Pennsylvania Working Papers in Linguistics, vol. 17(1). 175-184. https://repository. upenn.edu/pwpl/vol17/iss1/20.

Rooryck, Johan. 2018. French negation and restrictive focus. In Jan Ceuppens, Hans Smessaert, Jeroen van Craenenbroeck \& Guido Vanden Wyngaerd (eds.), A coat of many colors: A Festschrift for Dany Jaspers on the occasion of his 60th birthday. https://dj60.be/contents-7/.

Silvennoinen, Olli O. 2020. From constructions to functions and back: Contrastive negation in English and Finnish. Folia Linguistica 54(1). 45-87. https://doi.org/10.1515/ flin-2020-2027.

SSA = Kulonen, Ulla-Maija (toim.). 1995. Suomen sanojen alkuperä. Etymologinen sanakirja, vol. 2. Helsinki: Suomalaisen Kirjallisuuden Seura and Kotimaisten Kielten tutkimuskeskus.

Sudhoff, Stefan. 2010. Focus particles in German: Syntax, prosody, and information structure. Amsterdam / Philadelphia: John Benjamins.

Uusitupa, Milla. 2017. Rajakarjalaismurteiden avoimet persoonaviittaukset (Dissertations in Education, Humanities, and Theology 117). Joensuu: University of Eastern Finland. 
Vilkuna, Maria.1989. Free word order in Finnish. Its syntax and discourse functions. Helsinki: Suomalaisen Kirjallisuuden Seura.

Vilkuna, Maria 2015. Negation in Finnish. In Matti Miestamo, Anne Tamm \& Beata Wagner-Nagy (eds.), Negation in Uralic languages (Typological Studies in Language 108), 457-485. Amsterdam / Philadelphia: John Benjamins.

\begin{abstract}
Kokkuvõte. Maria Vilkuna: Soome keele välistav-eitav konstruktsioon $e i . . . k u(i) n$ välistust väljendavate keeleliste vahendite võrgustikus. Artiklis näidatakse, et soome keeles võib väljendada välistavat tähendust (nagu ainult) lausekonstruktsiooniga, mida artiklis nimetatakse välistavaks-eitavaks konstruktsiooniks (the Exclusive-Negative Construction, ENC). See sarnaneb prantsuse keele konstruktsiooniga ne...que, ent erineb sellest mitmes aspektis, kus soome ja prantsuse keel üldiseltki erinevad, eriti mis puudutab eituse väljendamise viise kahes keeles. Soome konstruktsioon sisaldab eksplitsiitset eitust, mis seletab seda, miks konstruktsiooni kasutusala on mõnevõrra kitsam kui selle alternatiivil, fookuspartiklil vain/vaan 'ainult'. Kasutades konstruktsioonigrammatika raamistikku, näidatakse artiklis, et ENC on lausekonstruktsioon, mille eripäraks on kahetine polaarsus: konstruktsioon jaotub vormiliselt eitavaks ja jaatavaks osaks. Väidetakse, et konstruktsioon ei ole tuletatud komparatiivikonstruktsioonist, kuid on seotud eksplitsiitsemalt välistust väljendavate vahenditega. Neid järeldusi toetavad murrete ja muu mittestandardse keelekasutuse andmed.
\end{abstract}

Märksõnad: ne...que konstruktsioon, fookuspartikkel, välistus, ekstseptiiv, eitus, konstruktsioonigrammatika, soome keel, prantsuse keel 